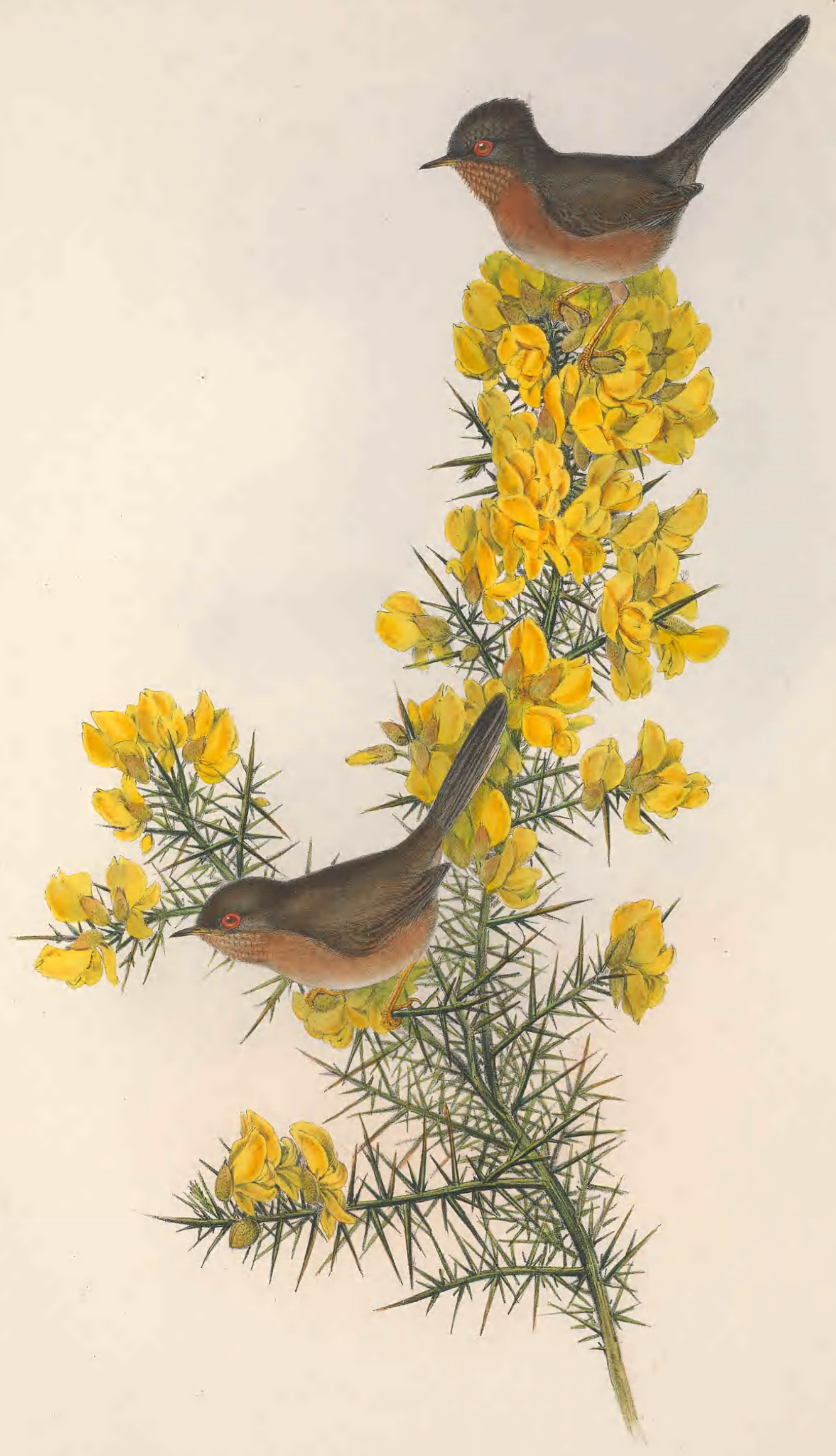




\title{
MELIZOPHILUS PROVINCIALIS.
}

\author{
Dartford Warbler.
}

Motacilla provincialis, Gmel. edit. Linn. Syst. Nat., tom. i. p. 958.

Sylvia Dartfordiensis, Lath. Ind. Orn., vol. ii. p. 517.

provincialis, Temm. Man. d'Orn., 2nd edit. tom. i. p. 210.

ferruginea, Vieill. Ency. Méth. Orn., pt. ii. p. 446.

Curruca provincialis, Flem. Brit. Anim., p. 70.

Melizophilus provincialis, Leach, Syst. Cat. of Spec. of Indig. Mamm. and Birds in Brit. Mus.

Frом the year 1773, when this bird was first noticed in England, on Bexley Heath, near Dartford, in Kent, to the present moment, it has been anxiously sought for by every ornithologist; yet how few have seen it in a state of nature! Still it is by no means scarce in all our southern and western counties; on the contrary, it is even more plentiful than other birds in the districts it inhabits. Those districts being of a peculiar character, the bird is a comparatively local one; at the same time it is a permanent resident with us, for it never leaves the furzy common and the heath, where, with the Titlark and Stone-Chat, it constitutes almost the only bird-life in the dreary months of winter. The extensive heathy lands of Surrey and Hampshire are its head quarters; it has, it is true, been found in other localities, but it is always less numerous and less certain to be met with. All the commons south of London, from Blackheath and Wimbledon to the coast, were formerly tenanted by this little bird; but the increase in the number of collectors has, I fear, greatly thinned them in all the districts near the metropolis ; it is still, however, very abundant in many parts of Surrey and Hampshire. In the midst of a tract of barren land, on the top of the lower green sandstone, near Farnham, is a small patch whereon cultivation has gained the ascendency over sterility; in this oasis dwells Mr. Smither, who is well acquainted with our native birds and insects, of which he is a sedulous collector. The Devil's Jumps (three hills so called) and the celebrated ponds of Frencham are in his immediate neighbourhood; and as Selborne is but a few miles over the heath, this district is within the area of Gilbert White's rambles, who, howerer, appears not to have been aware of the bird's existence there. Truthful to the letter are the stories which Smither relates respecting our native birds; and I therefore requested him to send me word what number of nests he had taken of the Dartford Warbler. The following reply will fully confirm what $I$ have said respecting the abundance of the bird in certain districts.

“The greatest number of Dartford Warblers' nests I ever procured in a season was 65. These were collected in 1859, within a very limited distance of this place, or within the parishes of Churt and Bramshot. I went out yesterday at daybreak, and shot three males and a female. The male at this time of the morning often sits on the top of the furze, raises the feathers on his head into a crest, and erects his tail like a Wren. Sometimes the winter is so severe as to kill the furze; then great numbers perish. Such, I am told, was the case forty years ago, and it was so in the winter of 1860 ; but still you could, I am sure, come dowu and shoot the bird at any time, if you wish to do so."

In the following May I and my son Franklin went down, for the purpose of seeing the Furze-Wren, as the bird is sometimes called, in a state of nature. We met with it near the highest of the Devil's Jumps, and found a nest with four eggs, built in a bunch of thick heather. This was in the middle of the breedingseason; for their nesting-time extends from the beginning of April to the end of July: the eggs found at this latter period are, of course, a second laying.

Besides the localities above mentioned, the Dartford Warbler is found on Selsey Common, near Portsmouth, in nearly every part of the New Forest, and on all furze-clad sides of hills near the sea, in the adjoining counties of Dorset and Devonshire; in Cornwall it becomes more scarce. North of London it is seldom seen, but it is found in Worcestershire, Leicestershire, and, I believe, in the neighbouring counties. On the continent of Europe it is very local; France is probably its northern limit, while in Spain it is numerous, and also in North Africa, as we learn from the Rev. H. B. Tristram's Notes on the Ornithology of that country, published in the first volume of 'The Ibis,' where he states, at page 418 , that it is " abundant in winter in the dayats, but never approaches the oases or the habitations of man. I do not believe that it is sedentary in the Sahara, but retires to the mountains to breed. I have taken several nests in the Atlas in the months of May and June."

As most British collectors must now be supplied with the eggs of the Furze-Wren, I trust Mr. Smither will be more sparing in future; for to him, as to us all, I am sure it must be a pleasure to see the numbers increase of this little native bird; on the other hand, should any young ornithologist be desirous of seeing it in a state of nature, he may always do so in the neighbourhood of Churt. Of course he would make his 
visit in the summer, when he would be well repaid by the novelty of the country, and otherwise pleased. Besides the Furze-Wren, the graceful Pewet will dippingly salute him while rambling over the common, the Cuckoo's note will resound in several directions, and the Stone-Chat will utter his clacking note from the topmost branch of the whin. The Wheatear and the Pipit will be almost the only other birds he will meet with; perchance, however, a Black Cock may rise at his feet, and spin away across the moor; but should our young friend remain until nightfall, which I should not recommend, he will be serenaded by the jarring note of the Goatsucker while sitting on one of the numerous turf-cocks.

The habits of the Dartford Warbler are shy, recluse, and mouse-like; the thickest beds of the whin or furze are its usual place of resort; but it not unfrequently affects open beds of heath, particularly such as are high enough to shroud it from observation. In the early morn, and often during the day, the male ascends to the highest spray and there pours forth his little warbling song; now and then it may be seen bobbingly flying from place to place, each flight terminating in a dive down into the thickest part of the covert, through which it creeps and runs with great quickness and facility. Were I to compare its actions and manners with those of any other English bird, it would be with those of the Whitethroat. Whoever is acquainted with that species and its short jerking flight, may form a very just idea of the manners of the Furze-Wren; perhaps I have said enough on this feature of the bird's economy, particularly as I subjoin the descriptive notes of Rusticus of Godalming; let me add, however, that there is little difference in the colouring of the sexes, but the female may always be distinguished by the lighter hue of her under surface.

"Its habits," says Rusticus, "are very like those of the Little Wren; and when the leaves are off the trees, and the dull winter winds have driven the summer birds to the olive-gardens of Spain, or across the Straits, the Furze-Wren, as it is called, is in the height of his enjoyment. I have seen them by dozens skipping about the furze, lighting for a moment on the very point of the sprigs, and instantly diving out of sight again, singing out their angry impatient ditty, for ever the same. Mounted on a tall horse, and riding quietly along the outside, while the fox-hounds have been drawing the furze-fields, I have seen the tops of the furze quite alive with these birds. They prefer those places where the furze is very thick, high, and difficult to get into."

The nest is built sometimes in a furze bush, at others among the standing heath on the Common, and is generally so placed as to be shronded from observation. One given to me by Mr. Alfred Crowley, of Croydon, was of a deep cup-shaped form, substantially built on the exterior with dry grass, straw, moss, and lichens; internally it was lined with very fine roots, and a small quantity of very coarse horse-hair.

The nest taken by myself and my son, at Churt, in May 1861, was built in a bunch of thick heather, to the many stems of which the nest was looped, much in the same manner as that of the Reed-Wren is to the reeds. The exterior was composed of the finer twigs of dead heather neatly woven together, and the interior was lined with the upper portions of the dry stems of grasses intermixed with a little wool.

The number of the eggs varies in about the following ratio: if 80 nests be examined, 30 of them will contain three, 48 will have four, and the remaining 2 five: so says Smither, and nobody knows better. The general colour of the eggs is a very light tinge of green, speckled all over with olive-brown and ashy grey, the markings being most numerous, and forming a zone, at the larger end.

Colonel Montagu says that some young birds brought up from the nest " began to sing with the appearance of their first mature feathers, and continued in song all the month of October, sometimes with scarcely any intermission, for several hours together; the notes were delivered in a hurried manner, and in a much lower tone than that of the old birds in their natural haunts."

The food of the Furze-Wren consists in summer of small dipterous and other insects, and in winter of minute Coleoptera and the small seeds of the heather.

Head, all the upper surface and wing-coverts very dark olive washed with grey on the ear-coverts; edge of the shoulder and spurious wing white; primaries and tail brownish black, the former margined with olive, the latter narrowly margined and tipped with grey, particularly the outer feathers; under surface chestnutbrown, the chin speckled with white, and the centre of the abdomen grey; irides golden hazel; eyelash very rich orange-red; bill yellow at the gape, passing into yellow-brown on the lower mandible; culmen and tips of both mandibles blackish brown. In the autumn the colouring of the plumage is paler, and the grey of the abdomen more extensive.

The Plate represents the two sexes of the natural size, on a branch of the Furze bush, Ulex Europaus. 


\section{$2 \mathrm{BHL}$ Biodiversity Heritage Library}

Gould, John. 1873. "Dartford Warbler, Melizophilus provincialis [PI. 59]." The birds of Great Britain 2, -. https://doi.org/10.5962/p.323873.

View This Item Online: https://www.biodiversitylibrary.org/item/221554

DOI: https://doi.org/10.5962/p.323873

Permalink: https://www.biodiversitylibrary.org/partpdf/323873

\section{Holding Institution}

Smithsonian Libraries

\section{Sponsored by}

Biodiversity Heritage Library

\section{Copyright \& Reuse}

Copyright Status: Public domain. The BHL considers that this work is no longer under copyright protection.

This document was created from content at the Biodiversity Heritage Library, the world's largest open access digital library for biodiversity literature and archives. Visit BHL at https://www.biodiversitylibrary.org. 